Article

\title{
Identification of Nematicidal Constituents of Notopterygium incisum Rhizomes against Bursaphelenchus xylophilus and Meloidogyne incognita
}

\author{
Gai Liu ${ }^{1}$, Daowan Lai ${ }^{2}$, Qi Zhi Liu ${ }^{1}$, Ligang Zhou ${ }^{2}$ and Zhi Long Liu ${ }^{1, *}$ \\ 1 Department of Entomology, China Agricultural University, Haidian District, Beijing 100193, China; \\ gailiu@126.com (G.L.); lqzwyz@cau.edu.cn (Q.Z.L.) \\ 2 Department of Plant Pathology, China Agricultural University, Haidian District, Beijing 100193, China; \\ dwlai@cau.edu.cn (D.L.); lgzhou@cau.edu.cn (L.Z.) \\ * Correspondence: zhilongliu@cau.edu.cn; Tel./Fax: +86-10-6273-2800 \\ Academic Editor: Derek J. McPhee \\ Received: 28 July 2016; Accepted: 20 September 2016; Published: 23 September 2016
}

\begin{abstract}
During a screening program for new agrochemicals from Chinese medicinal herbs, the ethanol extract of Notopterygium incisum rhizomes was found to possess strong nematicidal activity against the two species of nematodes, Bursaphelenchus xylophilus and Meloidogyne incognita. Based on bioactivity-guided fractionation, the four constituents were isolated from the ethanol extract and identified as columbianetin, falcarindiol, falcarinol, and isoimperatorin. Among the four isolated constituents, two acetylenic compounds, falcarindiol and falcarinol $(2.20-12.60 \mu \mathrm{g} / \mathrm{mL}$ and $1.06-4.96 \mu \mathrm{g} / \mathrm{mL}$, respectively) exhibited stronger nematicidal activity than two furanocoumarins, columbianetin, and isoimperatorin $(21.83-103.44 \mu \mathrm{g} / \mathrm{mL}$ and $17.21-30.91 \mu \mathrm{g} / \mathrm{mL}$, respectively) against the two species of nematodes, $B$. xylophilus and M. incognita. The four isolated constituents also displayed phototoxic activity against the nematodes. The results indicate that the ethanol extract of N. incisum and its four isolated constituents have potential for development into natural nematicides for control of plant-parasitic nematodes.
\end{abstract}

Keywords: Notopterygium incisum; Bursaphelenchus xylophilus; Meloidogyne incognita; nematicidal activity

\section{Introduction}

Plant-parasitic nematodes are a serious worldwide threat to forestry and agriculture because of their wide range of host plants and short biological cycles. It has been estimated that plant parasitic nematodes have caused as much as $\$ 100$ billion in annual losses of crops and plants worldwide [1]. The southern root-knot nematode (Meloidogyne incognita (Kofoid \& White) Chitwood) is the most economically important and widely distributed nematode throughout China, and considerable crop loss is caused by this nematode [1]. The pine wood nematode (Bursaphelenchus xylophilus (Steiner \& Buhrer) Nickle) causes pine wilt disease by inducing rapid wilting and leads to death of host pines [2]. Nematode management is generally based upon chemical treatments (soil fumigation, e.g., methylbromide and dichloropropane), but environmental concerns and governmental regulations are now resulting in a strong interest in nematicides of natural origin [3,4]. Plants are a prominent source of new nematicidal chemicals, since many plants have been reported to possess nematicidal activities [5-14]. A series of nematicidal substances of plant origin such as triglycerides, sesquiterpenoids, alkaloids, steroids, diterpenoids, monoterpenoids, and flavonoids have been identified [3,4,8-10,15-19]. 
During the screening program for new agrochemicals from Chinese medicinal herbs and wild plants, the ethanol extract of the rhizomes of Notopterygium incisum Ting ex H. T. Chang (Family: Umbelliferae) (Figure S1) was found to possess nematicidal toxicity against the two species of nematodes, B. xylophilus and M. incognita. Notopterygium incisum is perennial herb native to China (Gansu, Qinghai, Shaanxi, Sichuan province, and Tibet Autonomous Region). It grows at a range of 1600 to $5000 \mathrm{~m}$ above sea level and lives among forest edges and scrubs that border the grasslands of these elevated slopes [20]. The rhizomes of N. incisum known as "Qianghuo" in Chinese, is a well-known traditional Chinese medicinal herbs. They are used in herbal preparations for a series of symptoms from the common cold, chills, fever, rheumatoid arthritis, and general limb or body aches and pains [14]. Previous phytochemical investigations revealed that the rhizomes of $N$. incisum contained phenolic compounds, alkaloids, polyacetylenes, coumarins, sesquiterpenoids, and glycosides [21-34]. Pharmacological studies have revealed that its extracts or constituents possess anti-inflammatory, antioxidative, analgesic, and anti-influenza activity as well as antiproliferative activity against several cancer cell lines [21,22]. However, a literature survey shows that there is no report on nematicidal activity of the ethanol extract of $N$. incisum rhizomes. Thus, the objective of this study was to investigate the nematicidal activity of the ethanol extract of $N$. incisum rhizomes against the two species of nematodes and isolation of active constituents from the ethanol extract.

\section{Results and Discussion}

\subsection{Isolated Bioactive Compounds}

Four bioactive compounds were isolated and based on bioassay-guided fractionation and identified based on their spectroscopic data and comparison with literature vales. Their chemical structures are given in Figure 1.

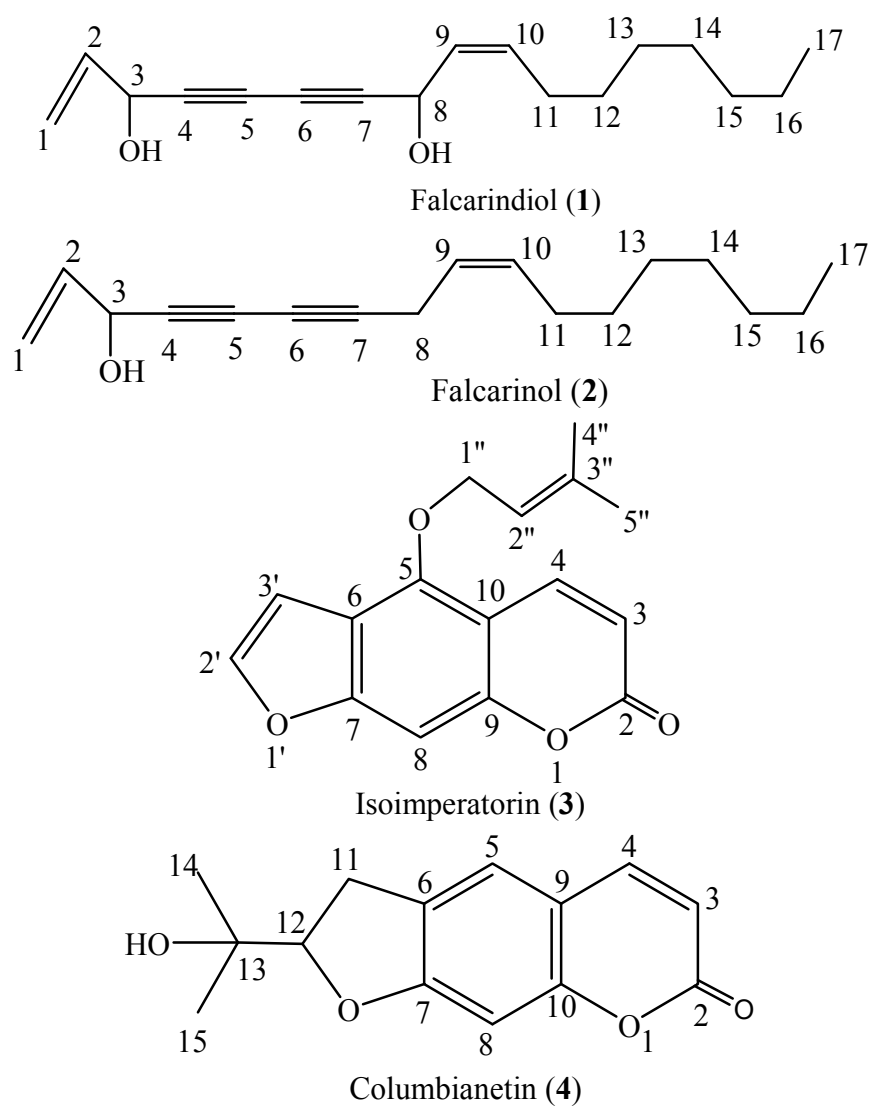

Figure 1. Constituent compounds isolated from the ethanol extract of Notopterygium incisum rhizomes. 


\subsection{Nematicidal Activity}

Among the four isolated constituents, falcarindiol and falcarinol exhibited strong nematicidal activity against the pine wood nematode (B. xylophilus) in dark with $\mathrm{LC}_{50}$ values of $2.20 \mu \mathrm{g} / \mathrm{mL}$ and $12.62 \mu \mathrm{g} / \mathrm{mL}$, respectively. Isoimperatorin and columbianetin also had LC 50 values of $21.83 \mu \mathrm{g} / \mathrm{mL}$ and $103.44 \mu \mathrm{g} / \mathrm{mL}$ against B. xylophilus, respectively (Table 1). Moreover, based on $\mathrm{LC}_{50}$ values, the two polyacetylene compounds demonstrated stronger nematicidal activity (no overlap of the 95\% FLs) than a positive control, $2 \%$ avermectin (dark, $\mathrm{LC}_{50}=3.57 \mu \mathrm{g} / \mathrm{mL}$ ) and two coumarins (isoimperatorin and columbianetin) against the pine wood nematodes (Table 1). When using $12 \mathrm{~h}$ light and $15 \mathrm{~min}$ UV light treatment, the nematicidal activity of the four isolated constituents against B. xylophilus increased. For example, falcarindiol had $\mathrm{LC}_{50}$ values of $0.95 \mu \mathrm{g} / \mathrm{mL}$ (light) and $0.73 \mu \mathrm{g} / \mathrm{mL}$ (UV) against B. xylophilus, two-to-three times more toxic than in dark (Table 1) while falcarinol showed almost nine times more toxic in UV light treatment than in dark against B. xylophilus. Moreover, after 15 min UV light treatment, the two coumarins also possessed two-to-three times more toxic to the pine wood nematodes than the dark treatment.

Table 1. Nematicidal activity of bioactive compounds from Notopterygium incisum rhizomes against Bursaphelenchus xylophilus.

\begin{tabular}{|c|c|c|c|c|c|}
\hline Compound & Treatment & $\mathrm{LC}_{50}(\mu \mathrm{g} / \mathrm{mL})(95 \% \mathrm{FL}) *$ & RT ** & $\mathrm{LC}_{90}(\mu \mathrm{g} / \mathrm{mL})(95 \% \mathrm{FL})^{*}$ & Slope \pm SE \\
\hline \multirow{3}{*}{ Columbianetin } & Dark & $103.44(84.52-123.10)$ & - & $375.11(288.16-560.48)$ & $2.29 \pm 0.21$ \\
\hline & Light & $72.12(59.98-83.82)$ & 1.43 & $268.50(217.65-361.20)$ & $2.25 \pm 0.24$ \\
\hline & UV & $32.11(25.05-38.74)$ & 3.22 & $85.64(67.29-128.53)$ & $3.01 \pm 0.34$ \\
\hline \multirow{3}{*}{ Falcarindiol } & Dark & $2.20(1.82-2.61)$ & - & $11.82(8.66-18.82)$ & $1.76 \pm 0.20$ \\
\hline & Light & $0.95(0.54-1.30)$ & 2.32 & $13.97(7.82-48.18)$ & $1.10 \pm 0.21$ \\
\hline & UV & $0.73(0.62-0.83)$ & 3.01 & $2.65(2.17-3.50)$ & $2.29 \pm 0.32$ \\
\hline \multirow{3}{*}{ Falcarinol } & Dark & $12.61(9.82-15.19)$ & - & 69.87 (54.61-100.05) & $1.72 \pm 0.20$ \\
\hline & Light & $7.42(4.93-9.66)$ & 1.69 & $30.79(21.45-63.14)$ & $1.63 \pm 0.30$ \\
\hline & UV & $1.43(1.15-1.71)$ & 8.82 & $3.98(3.18-5.54)$ & $2.88 \pm 0.23$ \\
\hline \multirow{3}{*}{ Isoimperatorin } & Dark & $21.83(16.66-27.54)$ & - & 236.64 (135.22-660.45) & $1.24 \pm 0.20$ \\
\hline & Light & $15.14(9.05-20.59)$ & 1.44 & 250.35 (128.36-1071.92) & $2.25 \pm 0.21$ \\
\hline & UV & $12.07(10.13-13.86)$ & 1.81 & $35.90(30.39-45.16)$ & $2.71 \pm 0.29$ \\
\hline Ethanol extract & Dark & $45.21(40.12-49.23)$ & - & 234.67 (211.56-256.78) & $2.23 \pm 0.24$ \\
\hline Avermectin & & $0.07(0.06-0.08)$ & - & $0.24(0.21-0.26)$ & $2.45 \pm 0.20$ \\
\hline
\end{tabular}

* Fiducial limits; ${ }^{* *}$ Relative toxicity $=\mathrm{LC}_{50}$ value in dark treatment $/ \mathrm{LC}_{50}$ values (in light or UV).

Based on $\mathrm{LC}_{50}$ values, the two polyacetylene compounds (falcarindiol and falcarinol, in dark $\mathrm{LC}_{50}=1.08 \mu \mathrm{g} / \mathrm{mL}$ and $4.96 \mu \mathrm{g} / \mathrm{mL}$, respectively) exhibited stronger nematicidal activity (no overlap of the $95 \%$ FLs) than two coumarins (isoimperatorin and columbianetin, dark treatment $\mathrm{LC}_{50}=7.57 \mu \mathrm{g} / \mathrm{mL}$ and $30.91 \mu \mathrm{g} / \mathrm{mL}$, respectively) against the southern root-knot nematodes (M. incognita) (Table 2). Falcarindiol also possessed the same level of nematicidal activity against the southern root-knot nematodes as the positive control, $2 \%$ avermectin (in dark, $\mathrm{LC}_{50}=1.25 \mu \mathrm{g} / \mathrm{mL}$ ) and the three other constituents showed less toxic than the positive control (Table 2). When using $15 \mathrm{~min}$ UV light treatment, falcarindiol, falcarinol, and isoimperatorin demonstrated almost five times more toxic to the southern root-knot nematodes than in dark treatment while columbianetin showed only two times more toxic (Table 2).

In the previous reports, several naturally occurring polyacetylenes have been demonstrated to possess toxic or phototoxic activity against insects, especially larval mosquitoes [35-40]. Falcarinol and falcarindiol were also demonstrated to possess larvicidal activity against the common house mosquito (Culex pipiens) with $24 \mathrm{~h} \mathrm{LC} 50$ values of $3.49 \mathrm{ppm}$ and $6.51 \mathrm{ppm}$, respectively [41]. There were several reports on nematicidal activity of natural occurring polyacetylenes (derived from Carthamus tinctorius) against plant parasitic nematodes such as, rice white tip nematode (Aphelencoides besseyi) with more than $80 \%$ mortality after five days at a concentration of 10 ppm treatment [42,43]. Moreover, 
14 polyacetylenes or their thiophene derivates, isolated from species of the Asteraceae were found to possess toxicity against adult nematodes (Caenorhabditis elegans) and toxicity of the compounds was found to be enhanced greatly by irradiation with near-UV radiation or natural sunlight [44]. However, their investigation with falcarindiol showed no photoactivation with UVA radiation [41]. Moreover, falcarinol and falcarindiol have been identified as antifungal compounds in many Apiaceae plant species inhibiting spore germination of different fungi in concentrations ranging from 20 to $200 \mu \mathrm{g} / \mathrm{mL}$ [45]. Falcarinol and falcarindiol also exhibited significant anti-Candida, antibacterial, and antimycobacterial activity, with an ability to kill Mycobacterium tuberculosis and isoniazid-resistant Mycobacterium avium at $10 \mu \mathrm{g} /$ disk in a disk diffusion assay [46]. However, this is the first report of nematicidal activity and photoactivation with UV treatment of falcarinol and falcarindiol against the two species of nematodes. The mode of action of falcarinol and falcarindiol on nematodes was not investigated; however, the mechanism for antifungal activity of falcarinol and falcarindiol is believed to involve disruption of cell membranes [47]. Thus, falcarinol, the more lipophilic compound, was more toxic than falcarindiol against the two species of nematodes, the more polar acetylene (Table 1). However, it was also suggested that the potent insecticidal action of falcarinol might be related to the GABAergic block associated with the higher intake expected in herbivorous insects because GABA $_{A}$ receptors are important targets of neuroactive pesticides [48,49].

Table 2. Nematicidal activity of bioactive compounds from Notopterygium incisum rhizomes against Meloidogyne incognita.

\begin{tabular}{cccccc}
\hline Compound & Treatment & LC $_{\mathbf{5 0}}(\boldsymbol{\mu g} / \mathbf{m L})(\mathbf{9 5} \% \mathbf{~ F L}){ }^{*}$ & RT $^{* *}$ & LC $_{\mathbf{9 0}}(\boldsymbol{\mu g} / \mathbf{m L})(\mathbf{9 5} \% \mathbf{F L})$ & Slope \pm SE \\
\hline \multirow{4}{*}{ Columbianetin } & Dark & $30.91(26.04-36.18)$ & - & $161.08(124.53-227.93)$ & $1.79 \pm 0.16$ \\
& Light & $28.29(14.78-40.44)$ & 1.09 & $171.12(138.24-262.45)$ & $1.61 \pm 0.27$ \\
& UV & $12.33(9.45-14.85)$ & 2.51 & $43.09(35.06-58.65)$ & $2.36 \pm 0.31$ \\
\hline \multirow{3}{*}{ Falcarindiol } & Dark & $1.08(0.89-1.28)$ & - & $5.99(4.36-9.68)$ & $1.72 \pm 0.20$ \\
& Light & $0.56(0.44-0.67)$ & 1.93 & $2.33(1.79-3.47)$ & $2.07 \pm 0.19$ \\
& UV & $0.22(0.15-0.29)$ & 4.91 & $2.31(1.54-4.65)$ & $1.26 \pm 0.09$ \\
\hline \multirow{3}{*}{ Falcarinol } & Dark & $4.96(4.20-5.76)$ & - & $24.00(19.10-32.27)$ & $1.87 \pm 0.15$ \\
& Light & $3.44(2.95-3.90)$ & 1.44 & $10.55(9.11-12.74)$ & $2.63 \pm 0.23$ \\
& UV & $1.00(0.86-1.15)$ & 4.96 & $5.50(4.12-8.30)$ & $1.73 \pm 0.17$ \\
\hline \multirow{2}{*}{ Isoimperatorin } & Dark & $17.21(14.86-19.85)$ & - & $74.55(58.88-101.81)$ & $1.79 \pm 0.19$ \\
& Light & $7.57(4.52-10.30)$ & 2.27 & $125.18(64.18-535.96)$ & $1.05 \pm 0.13$ \\
& UV & $3.30(1.96-4.46)$ & 5.22 & $18.22(14.41-26.25)$ & $1.73 \pm 0.17$ \\
\hline Ethanol extract & Dark & $22.34(19.89-24.67)$ & - & $130.56(119.25-142.79)$ & $1.56 \pm 0.14$ \\
\hline 2\% Avermectin & - & $0.03(0.02-0.03)$ & - & $0.24(0.22-0.27)$ & $2.08 \pm 0.16$ \\
\hline
\end{tabular}

${ }^{*}$ Fiducial limits; ${ }^{* *}$ Relative toxicity $=\mathrm{LC}_{50}$ value in dark treatment $/ \mathrm{LC}_{50}$ values (in light or UV).

Columbianetin and isoimperatorin had been demonstrated to possess insecticidal activity against several insects, such as the cabbage aphid (Brevicoryne brassicae), Egyptian cottonworm (Spodoptera littoralis), larvae of Aedes albopictus, A. aegypti, Culex pipiens pallens [50-52]. Columbianetin also exhibited antibacterial, antifungal, and cytotoxic activity [53-55]. However, this is first report of nematicidal activity against the two species of plant-parasitic nematodes.

The above findings suggest that nematicidal activity of the ethanol extract of $N$. incisum rhizomes and its four isolated constituents—especially the two polyacetylene compounds-against the two species of plant-parasitic nematodes is quite promising. As they are currently commonly used, nematicides are synthetic pesticides and these synthetic pesticides are also highly toxic to humans and other non-target organisms, the ethanol extract and its four isolated constituents show potential to be developed as possible natural nematicides for the control of B. xylophilus and M. incognita.

In traditional Chinese medicine, $N$. incisum rhizomes are used in herbal preparations for a series of symptoms from the common cold, chills, fever, rheumatoid arthritis, and general limb or body aches and pains [20]. It thus seems that this medicinal herb is quite safe for human consumption because it has been used as a medicinal herb for hundreds of years. Moreover, the four isolated 
constituents are naturally present in many vegetables and fruits, e.g., carrot, celery, parsley, coriander, ginseng, etc. Thus it seems that the four isolated constituents are quite safe for human consumption. However, no experimental data about the safety of this herb is available so far, so to develop a practical application for the ethanol extract and the isolated constituents as novel nematicides, further research on the safety of the extract/compounds to humans is needed.

\section{Experimental}

\subsection{General}

${ }^{1} \mathrm{H}$ and ${ }^{13} \mathrm{C}-\mathrm{NMR}$ spectra were recorded on Bruker Avance ACF300 (300 MHz $(1 \mathrm{H})$ ) and Bruker Avance AMX500 (500 MHz (1H), Bruker BioSpin AG, Fällanden, Switzerland) instruments using $\mathrm{CDCl}_{3}$ as the solvent with TMS as internal standard.

\subsection{Plant Material and Extraction}

The dried rhizomes of $N$. incisum ( $5 \mathrm{~kg}$ ) were purchased from Anguo Chinese Medicinal Herbs Market (Anguo, Hebei, China), which harvested from Gansu Province, China. The species was identified by Dr QR Liu, College of Life Sciences, Beijing Normal University, Beijing, China. A voucher specimen of N. incisum (No. CMH-Qianghuo-Gansu-2015-08) was deposited at the museum of the Department of Entomology, China Agricultural University, Beijing, China.

The dried rhizomes were cut into pieces and then successively extracted with $40 \mathrm{~L}$ different concentrations of ethanol/ tap water mixtures (95\%,75\%,50\%, by volume) and tap water at room temperature for three days. The extracts were then filtered, mixed and concentrated under vacuum to afford crude extract (800 g). After that, the crude extract was diluted with distilled water $(2 \mathrm{~L})$ and then successively partitioned with the same volume of $n$-hexane, chloroform, ethyl acetate and $n$-butyl alcohol. Each partition was concentrated separately to obtain four solvent fractions $(27 \mathrm{~g}, 86 \mathrm{~g}, 31 \mathrm{~g}$, $32 \mathrm{~g}$ ) and stored in brown glass bottles at $4{ }^{\circ} \mathrm{C}$ for further experiments.

\subsection{Bioassay-Directed Fractionation}

The crude ethanol extract and its four solvent fractions were screened for their nematicidal potential against juveniles of the two species of nematodes as described below. On the basis of $72 \mathrm{~h}$ mortalities at a concentration of $1000 \mu \mathrm{g} / \mathrm{mL}$, the most active (chloroform fraction) was subjected to further fractionation.

The chloroform fraction of $N$. incisum extracts was chromatographed on a silica gel (Merck grade 9385, 230-400 mesh, Darmstadt, Germany, 1000 g) column (85 mm i.d., 850 mm length), eluting with a solvent system (petroleum ether/ethyl acetate/ethanol, by volume) of increasing polarity. Column fractions were analyzed by TLC (precoated GF254 plate; Qingdao Marine Chemical Plant, Qingdao, China) profiles and similar fractions were combined to yield 12 fractions (Fa1-Fa14). Nematicidal activity bioassays of these fractions were evaluated at a concentration of $1000 \mu \mathrm{g} / \mathrm{mL}$ to afford four bioactive principles (Fa2, Fa4, Fa6, Fa7). Fa2 was submitted to preparative silica gel column chromatography (PTLC) (precoated GF254 plate) using petroleum ether/ethyl acetate (100:5, by volume) as an eluent to give isoimperatorin (15 mg). The other three fractions were further purified by silica gel (Merck grade 9385, 230-400 mesh, 300 g) column (10 mm i.d., 500 mm length) chromatography using a petroleum ether/ethyl acetate solvent system and by PTLC as well as by Sephadex LH-20 column, to get compounds with the following order: columbianetin (18 mg), falcarinol (25 mg), and falcarindiol (22 mg). The structure of the compounds was elucidated based on nuclear magnetic resonance (Figures S2-S5).

\subsection{Nematodes}

Eggs of M. incognita were extracted from infected roots of tomato (Solanum lycopersicum L.). All the tomatoes were reared in a growth chamber $\left(16: 8 \mathrm{~h} \mathrm{~L}: \mathrm{D}, 25-28{ }^{\circ} \mathrm{C}, 75 \%-80 \% \mathrm{RH}\right)$. When reaching the 
five-leaf stage, tomato plants were used for inoculations; and 43 days later, infected tomato plants were uprooted and the roots were washed free of soil with tap water. Egg masses were hand-picked using sterilized tweezers from infected roots and rinsed three times with sterilized distilled water. To obtain second-stage juveniles (J2) of M. incognita, egg masses were placed on a mesh nylon filter (openings $30 \mu \mathrm{m}$ in diameter) [56]. J2s that passed through the filter were collected daily and used for bioassays immediately.

B. xylophilus was collected from sawdusts of infected pine woods in Fuling District, Chongqing City, China (29.70 $\mathrm{N}$ and $\left.107.39^{\circ} \mathrm{E}\right)$ in September 2015, and obtained through the modified Baermann funnel technique [57]. Colonies of B. xylophilus were maintained on Botrytis cinerea cultures. The fungus $B$. cinerea was cultured on potato dextrose agar (PDA) in a growth chamber $\left(25-28^{\circ} \mathrm{C}\right.$ in dark). When B. cinerea was fully grown on PDA, the plates were inoculated with B. xylophilus and cultured in the growth chamber $\left(25-28^{\circ} \mathrm{C}\right.$ in dark) until the fungal mycelium were completely consumed by B. xylophilus. Then, B. xylophilus were collected using the modified Baermann funnel technique [48], washed with a mixture of $0.1 \%$ streptomycin sulfate and $0.002 \%$ actinone three times to remove any surface bacterial or fungal contaminants and immediately used for bioassays.

\subsection{Nematicidal Activity Bioassays}

Nematicidal activity bioassays of $M$. incognita were taken under laboratory conditions at $25-28^{\circ} \mathrm{C}$. The standard nematode suspensions of $M$. incognita were prepared by appropriate dilution with sterilized distilled water to get approximately $100 \mathrm{~J} 2 \mathrm{~s} / \mathrm{mL}$. All the tested extracts or compounds were dissolved in ethanol and diluted with distilled water to obtain stock solutions of double the treatment concentrations, which were determined by a series of range-finding tests. However, the final concentration of ethanol in each treatment never exceeded 1\% (by volume). Then, each well of 24-well tissue culture plates were added with $500 \mu \mathrm{L}$ standard J2 suspension. Numbers of active J2 in every well were counted under a stereoscope at $10 \times$ and $5 \times$ before $500 \mu \mathrm{L}$ stock solution was added to the corresponding well. Plates were then covered with rice paper to avoid evaporation. Each test was composed of five concentrations with three replicates. Commercial avermectin (purchased from Aladdin-Reagent Company, Shanghai, China)—serving as a positive control and distilled water containing ethanol ( $1 \%$, by volume)-was used as a negative control. Both treated and control J2 nematodes were placed in a growth chamber at $25-28{ }^{\circ} \mathrm{C}$ in dark or in light. To measure photoactive effect, $15 \mathrm{~min}$ UV radiation was provided and the treated sets were placed to the growth chamber at $25-28^{\circ} \mathrm{C}$ in dark. Mortality recordings were taken $72 \mathrm{~h}$ after treatment. J2 nematodes that showed no movements when stimulated with a fine needle were considered to be dead.

Nematicidal activity bioassays of B. xylophilus were taken as almost the same as M. incognita bioassays, but only juveniles were used.

\subsection{Isolated Constituent Compounds}

Falcarindiol (1, Figure 1). Brownish oil, ${ }^{1} \mathrm{H}-\mathrm{NMR}\left(\mathrm{CDCl}_{3}, 500 \mathrm{MHz}\right) \delta(\mathrm{ppm}): \delta 6.00-5.92(1 \mathrm{H}, \mathrm{m}, \mathrm{H}-2)$, $5.64(1 \mathrm{H}, \mathrm{dd}, J=17.8,7.7 \mathrm{~Hz}, \mathrm{H}-10), 5.52(2 \mathrm{H}, \mathrm{dd}, J=24.3,13.4 \mathrm{~Hz}, \mathrm{H}-1), 5.23(1 \mathrm{H}, \mathrm{d}, J=8.3 \mathrm{~Hz}, \mathrm{H}-8)$, $4.97(1 \mathrm{H}, \mathrm{d}, J=4.8 \mathrm{~Hz}, \mathrm{H}-3), 2.13(2 \mathrm{H}, \mathrm{q}, J=7.4 \mathrm{~Hz}, \mathrm{H}-11), 1.44-1.37$ (3H, m, H-12), 1.29 (8H, d, J = 10.5 $\mathrm{Hz}, \mathrm{H}-13,14,15,16), 0.90(3 \mathrm{H}, \mathrm{t}, J=6.4 \mathrm{~Hz}, \mathrm{H}-17) .{ }^{13} \mathrm{C}-\mathrm{NMR}\left(\mathrm{CDCl}_{3}, 125 \mathrm{MHz}\right) \delta(\mathrm{ppm}): 135.8(\mathrm{C}-2)$, 134.7 (C-10), 127.6 (C-9), 117.4 (C-1), 78.8 (C-7), 78.4 (C-4), 72.4 (C-5), 63.6 (C-6), 63.5 (C-3), 58.6 (C-8), 31.8 (C-11), 29.28-29.07 (C-12, 13, 14), 27.8 (C-15), 22.7 (C-16), 14.1 (C-17). The data matched with previous reports $[58,59]$.

Falcarinol (2, Figure 1). Yellow oil, ${ }^{1} \mathrm{H}-\mathrm{NMR}\left(\mathrm{CDCl}_{3}, 500 \mathrm{MHz}\right) \delta$ (ppm): 5.96 (1H, ddd, $J=17.0,10.1$, $5.4 \mathrm{~Hz}, \mathrm{H}-10), 5.53-5.50(1 \mathrm{H}, \mathrm{m}, \mathrm{H}-10), 5.47(1 \mathrm{H}, \mathrm{s}, \mathrm{H}-1), 5.40(1 \mathrm{H}, \mathrm{d}, J=10.5 \mathrm{~Hz}, \mathrm{H}-9), 5.28-5.24(1 \mathrm{H}, \mathrm{m}$, H-1), $4.94(1 \mathrm{H}, \mathrm{d}, J=5.3 \mathrm{~Hz}, \mathrm{H}-3), 3.06(2 \mathrm{H}, \mathrm{dd}, J=6.9,0.7 \mathrm{~Hz}, \mathrm{H}-8), 2.06(1 \mathrm{H}, \mathrm{d}, J=7.8 \mathrm{~Hz}, \mathrm{H}-3), 2.04$ (1H, s, H-11), 1.40-1.36 (2H, m, H-12), 1.31-1.29 (8H, m, H-13, 14, 15, 16), 0.90 (3H, t, J = 6.9 Hz, H-17). ${ }^{13} \mathrm{C}-\mathrm{NMR}\left(\mathrm{CDCl}_{3}, 125 \mathrm{MHz}\right) \delta$ (ppm): 136.1 (C-2), 133.1 (C-10), 121.9 (C-9), 117.1 (C-1), 80.3 (C-7), 74.2 
(C-4), 71.3 (C-5), 64.0 (C-6), 63.6 (C-3), 31.8 (C-15), 29.2 (C-12, 13, 14), 27.2 (C-11), 22.6 (C-16), 17.7 (C-8), 14.1 (C-17). The data matched with previous reports [58,59].

Isoimperatorin (3, Figure 1). Crystal, ${ }^{1} \mathrm{H}-\mathrm{NMR}\left(\mathrm{CDCl}_{3}, 500 \mathrm{MHz}\right) \delta(\mathrm{ppm}): 8.18(1 \mathrm{H}, \mathrm{d}, J=9.8 \mathrm{~Hz}, \mathrm{H}-4)$, $7.62\left(1 \mathrm{H}, \mathrm{s}, \mathrm{H}-2^{\prime}\right), 7.18(1 \mathrm{H}, \mathrm{s}, \mathrm{H}-8), 6.98\left(1 \mathrm{H}, \mathrm{s}, \mathrm{H}-3^{\prime}\right), 6.29(1 \mathrm{H}, \mathrm{d}, J=9.7 \mathrm{~Hz}, \mathrm{H}-3), 5.56(1 \mathrm{H}, \mathrm{t}, J=6.4 \mathrm{~Hz}$, H-2"), $4.94\left(2 \mathrm{H}, \mathrm{d}, J=7.0 \mathrm{~Hz}, \mathrm{H}-1^{\prime}\right), 1.82\left(3 \mathrm{H}, \mathrm{s}, \mathrm{H}-4^{\prime \prime}\right), 1.72\left(3 \mathrm{H}, \mathrm{s}, \mathrm{H}-5^{\prime \prime}\right) .{ }^{13} \mathrm{C}-\mathrm{NMR}\left(\mathrm{CDCl}_{3}, 125 \mathrm{MHz}\right)$ $\delta$ (ppm): 161.4 (C-2), 158.2 (C-7), 152.7 (C-9), 149.0 (C-5), 144.9 (C-2'), 139.8 (C-3"), 139.7 (C-4), 119.1 (C-2"), 114.3 (C-6), 112.5 (C-3), 107.6(C-10), 105.0 (C-3'), 94.3 (C-8), 69.8 (C-1"), 25.8 (C-4"), 18.2 (C-5"). The data matched with previous reports [50].

Columbianetin (4, Figure 1). Crystal, ${ }^{1} \mathrm{H}-\mathrm{NMR}(\mathrm{MeOD}, 500 \mathrm{MHz}) \delta(\mathrm{ppm}): \delta 7.88(1 \mathrm{H}, \mathrm{d}, J=9.5 \mathrm{~Hz}$, H-4), $7.43(1 \mathrm{H}, \mathrm{s}, \mathrm{H}-5), 6.75$ (1H, s, H-8), $6.22(1 \mathrm{H}, \mathrm{d}, J=9.5 \mathrm{~Hz}, \mathrm{H}-3), 4.78$ (1H, t, J = 8.7 Hz, H-12), 3.28 $(2 \mathrm{H}, \mathrm{d}, J=9.6 \mathrm{~Hz}, \mathrm{H}-11), 1.32$ (3H, s, H-14), 1.26 (3H, s, H-15). ${ }^{13} \mathrm{C}-\mathrm{NMR}$ (MeOD, $\left.125 \mathrm{MHz}\right) \delta$ (ppm): 163.9 (C-7), 162.4 (C-2), 155.5 (C-10), 144.9 (C-4), 125.9 (C-6), 123.6 (C-5), 112.7 (C-9), 110.8 (C-3), 96.8 (C-8), 91.1 (C-12), 70.9 (C-13), 28.9 (C-11), 24.0 (C-14), 23.9 (C-15). The data matched with previous reports $[59,60]$.

\subsection{Data Analysis}

Data were corrected for control mortality using Abbott's formula [61]. $\mathrm{LC}_{50}$ and $\mathrm{LC}_{90}$ values, along with $95 \%$ confidence limits (CLs), and chi-square values were calculated using SPSS 14.0 software. $\mathrm{LC}_{50}$ values of the tested materials were considered to be significantly different when their $95 \%$ confidence limits (CLs) failed to overlap. Chi-square values were significant at the $p<0.05$ level.

\section{Conclusions}

The present work indicated that the ethanol extract of $N$. incisum rhizomes and its four isolated constituents demonstrated strong nematicidal activity against B. xylophilus and Meloidogyne incognita. Our results suggested that the extract of $N$. incisum rhizomes and its four isolated constituents, especially falcarinol and falcarindiol, have potential for development into natural nematicides for control of plant-parasitic nematodes.

Supplementary Materials: Supplementary materials can be accessed at: http:/ /www.mdpi.com/1420-3049/21/ $10 / 1276 / \mathrm{s} 1$.

Acknowledgments: This project was supported by National Key Technology Research and Development Program of Ministry of Science and Technology of China (grant No. 2014BAD23B02). We thank Liu Q.R. from the College of Life Sciences, Beijing Normal University, Beijing 100875, China, for the identification of the investigated plant.

Author Contributions: Z.L.L. and Q.Z.L. conceived and designed the experiments; G.L. performed the experiments; D.L. and L.Z. analyzed the data; Q.Z. L. contributed reagents/materials/analysis tools; Z.L.L. wrote the paper."

Conflicts of Interest: The authors declare no conflict of interest. The founding sponsors had no role in the design of the study; in the collection, analyses, or interpretation of data; in the writing of the manuscript, and in the decision to publish the results.

\section{References}

1. Li, W.; Sun, Y.N.; Yan, X.T.; Yang, S.Y.; Lee, S.J.; Byun, H.J.; Moon, C.S.; Han, B.S.; Kim, Y.H. Isolation of nematicidal triterpenoid saponins from Pulsatilla koreana root and their activities against Meloidogyne incognita. Molecules 2013, 18, 5306-5316. [CrossRef] [PubMed]

2. Guo, Q.; Du, G.; Qi, H.; Zhang, Y.; Yue, T.; Wang, J.; Li, R. A nematicidal tannin from Punica granatum L. rind and its physiological effect on pine wood nematode (Bursaphelenchus xylophilus). Pestic. Biochem. Physiol. 2016. [CrossRef]

3. Caboni, P.; Ntalli, N.G. Botanical nematicides, recent findings. ACS Symp. 2014, 1172, 145-157.

4. Ntalli, N.G.; Caboni, P. Botanical nematicides: A review. J. Agric. Food Chem. 2012, 60, 9929-9940. [CrossRef] [PubMed] 
5. Choi, N.H.; Kwon, H.R.; Son, S.W.; Choi, Y.H.; Jang, K.S.; Lee, S.O.; Choi, J.E.; Ngoc, L.H.; Kim, J.C. Nematicidal activity of malabaricones isolated from Myristica malabarica fruit rinds against Bursaphelenchus xylophilus. Nematology 2008, 10, 801-807. [CrossRef]

6. Bai, C.Q.; Liu, Z.L.; Liu, Q.Z. Nematicidal constituents from the essential oil of Chenopodium ambrosioides aerial parts. E. J. Chem. 2011, 8, S143-S148. [CrossRef]

7. Du, S.S.; Zhang, H.M.; Bai, C.Q.; Wang, C.F.; Liu, Q.Z.; Liu, Z.L.; Wang, Y.Y.; Deng, Z.W. Nematocidal flavone-C-glycosides against the root-knot nematodes (Meloidogyne incognita) from Arisaema erubescens tubers. Molecules 2011, 16, 5079-5086. [CrossRef] [PubMed]

8. Zhang, H.M.; Wang, G.L.; Bai, C.Q.; Liu, P.; Liu, Z.M.; Liu, Q.Z.; Wang, Y.Y.; Liu, Z.L.; Du, S.S.; Deng, Z.W. A new eudesmane sesquiterpene glucoside from Liriope muscari fibrous roots. Molecules 2011, 16, 9017-9024. [CrossRef] [PubMed]

9. Caboni, P.; Ntalli, N.G.; Aissani, N.; Cavoski, I.; Angioni, A. Nematicidal activity of (E,E)-2,4-decadienal and (E)-2-decenal from Ailanthus altissima against Meloidogyne javanica. J. Agric. Food Chem. 2012, 60, 1146-1151. [CrossRef] [PubMed]

10. Liu, Q.Z.; Li, H.Q.; Liu, Z.L. Nematicidal constituents from the ethanol extract of Evodia rutaecarpa Hort unripe fruits. J. Chem. 2013. [CrossRef]

11. Caboni, P.; Saba, M.; Oplos, C.; Aissani, N.; Maxia, A.; Menkissoglu-Spiroudi, U.; Casua, L.; Ntalli, N. Nematicidal activity of furanocoumarins from parsley against Meloidogyne spp. Pest Manag. Sci. 2014, 71, 1099-1105. [CrossRef] [PubMed]

12. Li, Y.C.; Ji, H.; Li, H.T. Gas chromatography-mass spectrometric analysis of nematicidal essential oil of Valeriana amurensis P Smirn ex Kom (Valerianaceae) roots and its activity against Heterodera avenae. Trop. J. Pharm. Res. 2015, 14, 1673-1678.

13. Naz, I.; Abdulkafi, S.; Munir, I.; Ahmad, M.; Ali, A.; Palomares-Rius, J.E.; Ali, S.; Ahmad, I. Cis- and trans-protopinium, a novel nematicide, for the eco-friendly management of root-knot nematodes. Crop Prot. 2016, 81, 138-144. [CrossRef]

14. Begum, S.; Ayub, A.; Shaheen Siddiqui, B.; Fayyaz, S.; Kazi, F. Nematicidal triterpenoids from Lantana camara. Chem. Biodivers. 2015, 12, 1435-1442. [CrossRef] [PubMed]

15. Faria, J.M.S.; Sena, I.; Ribeiro, B.; Rodrigues, A.M.; Maleita, C.M.N.; Abrantes, I.; Bennett, B.; Mota, M.; Figueiredo, A.C.S. First report on Meloidogyne chitwoodi hatching inhibition activity of essential oils and essential oils fractions. J. Pest Sci. 2016, 89, 207-217. [CrossRef]

16. Faria, J.M.S.; Sena, I.; Moiteiro, C.; Bennett, R.N.; Mota, M.; Figueiredo, A.C. Nematotoxic and phytotoxic activity of Satureja montana and Ruta graveolens essential oils on Pinus pinaster shoot cultures and P. pinaster with Bursaphelenchus xylophilus in vitro co-cultures. Ind. Crop. Prod. 2015, 77, 59-65. [CrossRef]

17. Faria, J.M.S.; Barbosa, P.; Bennett, R.N.; Mota, M.; Figueiredo, A.C.S. Bioactivity against Bursaphelenchus xylophilus: Nematotoxics from essential oils, essential oils fractions and decoction waters. Phytochemistry 2013, 94, 220-228. [CrossRef] [PubMed]

18. Barbosa, P.; Faria, J.M.S.; Mendes, M.D.; Dias, L.S.; Tinoco, M.T.; Barroso, J.G.; Pedro, L.G.; Figueiredo, A.C.; Mota, M. Bioassays against pinewood nematode: Assessment of suitable dilution agent and screening for bioactive essential oils. Molecules 2012, 17, 12312-12329. [CrossRef] [PubMed]

19. Barbosa, P.; Lima, A.S.; Vieira, P.; Dias, L.S.; Tinoco, M.T.; Barroso, J.G.; Pedro, L.G.; Figueiredo, A.C.; Mota, M. Nematicidal activity of essential oils and volatiles derived from Portuguese aromatic flora against the pinewood nematode, Bursaphelenchus xylophilus. J. Nematol. 2010, 42, 8-16. [PubMed]

20. Notopterygium incisum. Flora of China. Available online: http://www.efloras.org/florataxon.aspx?flora_id= 2\&taxon_id=200015680 (accessed on 26 July 2016).

21. Blunder, M.; Liu, X.; Kunert, O.; Winkler, N.A.; Schinkovitz, A.; Schmiderer, C.; Novak, J.; Bauer, R. Polyacetylenes from Radix et rhizoma Notopterygii incisi with an inhibitory effect on nitric oxide production in vitro. Planta Med. 2014, 80, 415-418. [CrossRef] [PubMed]

22. Liu, X.; Kunert, O.; Blunder, M.; Fakhrudin, N.; Noha, S.M.; Malainer, C.; Schinkovitz, A.; Heiss, E.H.; Atanasov, A.G.; Kollroser, M.; et al. Polyyne hybrid compounds from Notopterygium incisum with peroxisome proliferator-activated receptor gamma agonistic effects. J. Nat. Prod. 2014, 77, 2513-2521. [CrossRef] [PubMed] 
23. Atanasov, A.G.; Blunder, M.; Fakhrudin, N.; Liu, X.; Noha, S.M.; Malainer, C.; Kramer, M.P.; Cocic, A.; Kunert, O.; Schinkovitz, A.; et al. Polyacetylenes from Notopterygium incisum-New selective partial agonists of peroxisome proliferator-activated receptor-gamma. PLoS ONE 2013, 8, e61755. [CrossRef] [PubMed]

24. Xu, K.; Jiang, S.; Sun, H.; Zhou, Y.; Xu, X.; Peng, S.; Ding, L. New alkaloids from the seeds of Notopterygium incisum. Nat. Prod. Res. 2012, 26, 1898-1903. [CrossRef] [PubMed]

25. You, M.; Xiong, J.; Zhao, Y.; Cao, L.; Wu, S.-B.; Xia, G.; Hu, J.-F. Glycosides from the methanol extract of Notopterygium incisum. Planta Med. 2011, 77, 1939-1943. [CrossRef] [PubMed]

26. Kou, G.; Zhang, Y.; Yang, X.; Rong, R. O-Methylnotopterol, a new natural product from the roots and rhizomes of Notopterygium incisum. Chin. J. Chin. Mater. Med. 2010, 35, 1134-1136. (In Chinese with English Abstract)

27. Wu, S.B.; Zhao, Y.; Fan, H.; Hu, Y.H.; Hamann, M.T.; Peng, J.N.; Starks, C.M.; O’Neil-Johnson, M.; Hu, J.F. New guaiane sesquiterpenes and furanocoumarins from Notopterygium incisum. Planta Med. 2008, 74, 1812-1817. [CrossRef] [PubMed]

28. Wu, S.B.; Yu, Y.H.; Hu, Y.H.; Hu, J.F. A new dimeric furanocoumarin from Notopterygium incisum. Chin. Chem. Lett. 2008, 19, 940-942. [CrossRef]

29. Xiao, Y.Q.; Baba, K.; Taniguchi, M.; Liu, X.H.; Sun, Y.F.; Kozawa, M. Coumarins from Notopterygium incisum Ting. Acta Pharm. Sin. 1995, 30, 274-279. (In Chinese with English Abstract)

30. Xiao, Y.Q.; Liu, X.H.; Sun, Y.F.; Baba, K.; Taniguchi, M.; Kozawa, M. Three new furocoumarins from Notopterygium incisum Ting. Chin. Chem. Lett. 1994, 5, 593-596.

31. Gu, Z.; Zhang, D.; Yang, X.; Hattori, M.; Namba, T. Isolation of two new coumarin glycosides from Notopterygium forbesii and evaluation of a Chinese crude drug, Qiang-Huo, the underground parts of N. incisum and N. forbesii, by high-performance liquid chromatography. Chem. Pharm. Bull. 1990, 38, 2498-2502. [CrossRef] [PubMed]

32. Kozawa, M.; Fukumoto, M.; Matsuyama, Y.; Baba, K. Chemical studies on the constituents of the Chinese crude drug Qiang Huo. Chem. Pharm. Bull. 1983, 31, 2712-2717. [CrossRef]

33. Wu, S.B.; Pang, F.; Wen, Y.; Zhang, H.F.; Zhao, Z.; Hu, J.F. Antiproliferative and apoptotic activities of linear furocoumarins from Notopterygium incisum on cancer cell lines. Planta Med. 2010, 76, 82-85. [CrossRef] [PubMed]

34. Matsuda, H.; Sato, N.; Tokunaga, M.; Naruto, S.; Kubo, M. Bioactive constituent of Notopterygii rhizoma, falcarindiol having antibacterial activity against Staphylococcus aureus isolated from patients with atopic dermatitis. Nat. Med. (Tokyo Jpn.) 2002, 56, 113-116.

35. Arnason, T.; Swain, T.; Wat, C.K.; Graham, E.A.; Partington, S.; Towers, G.H.N.; Lam, J. Mosquito larvicidal activity of polyacetylenes from species in the Asteraceae. Biochem. Syst. Ecol. 1981, 9, 63-68. [CrossRef]

36. Wang, Y.; Toyota, M.; Krause, F.; Hamburger, M.; Hostettmann, K. Polyacetylenes from Artemisia borealis and their biological activities. Phytochemistry 1990, 29, 3101-3015.

37. Guillet, G.; Philogene, B.J.R.; O'meara, J.; Durst, T.; Arnason, J.T. Multiple modes of insecticidal action of three classes of polyacetylene derivatives from Rudbeckia hirta. Phytochemistry 1997, 46, 495-498. [CrossRef]

38. Tian, Y.Q.; Wei, X.Y.; Xu, H.H. Photoactivated insecticidal thiophene derivatives from Xanthopappus subacaulis. J. Nat. Prod. 2006, 69, 1241-1244. [CrossRef] [PubMed]

39. Dalila, H.; Flamini, G.; Ben Halima-Kamel, M.; Ben Hamouda, M.H. Identification of an insecticidal polyacetylene derivative from Chrysanthemum macrotum leaves. Ind. Crop. Prod. 2011, 34, 1128-1134.

40. Nakano, H.; Ali, A.; Ur Rehman, J.; Mamonov, L.K.; Cantrell, C.L.; Khan, I.A. Toxicity of thiophenes from Echinops transiliensis (Asteraceae) against Aedes aegypti (Diptera: Culicidae) larvae. Chem. Biodivers. 2014, 11, 1001-1009. [CrossRef] [PubMed]

41. Eckenbach, U.; Lampman, R.L.; Seigler, D.S.; Ebinger, J.; Novak, R.J. Mosquitocidal activity of acetylenic compounds from Cryptotaenia canadensis. J. Chem. Ecol. 1999, 25, 1885-1893. [CrossRef]

42. Kogiso, S.; Wada, K.; Munakata, K. Isolation of nematicidal polyacetylenes from Carthamus tinctorius L. Agric. Biol. Chem. 1976, 40, 2085-2089. [CrossRef]

43. Kogiso, S.; Wada, K.; Munakata, K. Nematicidal polyacetylenes, 3Z, 11E- and 3E, 11E-trideca-1,3,11-triene-5, 7,9-triyne from Carthamus tinctorius L. Tetrahedron Lett. 1976, 17, 109-110. [CrossRef]

44. Wat, C.K.; Prasad, S.K.; Graham, E.A.; Partington, S.; Arnason, T.; Towers, G.H.N.; Lam, J. Photosensitization of invertebrates by natural polyacetylenes. Biochem. Syst. Ecol. 1981, 9, 59-62. [CrossRef] 
45. Christensen, L.P.; Brandt, K. Bioactive polyacetylenes in food plants of the Apiaceae family: Occurrence, bioactivity and analysis. J. Pharm. Biomed. Anal. 2006, 41, 683-693. [CrossRef] [PubMed]

46. Kobaisy, M.; Abramowski, Z.; Lermer, L.; Saxena, G.; Hancock, R.E.W.; Towers, G.H.N. Antimycobacterial polyynes of Devil's club (Oplopanax horridus), a North American native medicinal plant. J. Nat. Prod. 1997, 60, 1210-1213. [CrossRef] [PubMed]

47. Garrod, B.; Lea, E.J.A.; Lewis, G. Studies on the mechanism of action of the antifungal compound falcarindiol. New Phytol. 1979, 83, 463-471. [CrossRef]

48. Czyzewska, M.M.; Chrobok, L.; Kania, A.; Jatczak, M.; Pollastro, F.; Appendino, G.; Mozrzymas, J.W. Dietary acetylenic oxylipin falcarinol differentially modulates GABA A receptors. J. Nat. Prod. 2014, 77, 2671-2677. [CrossRef] [PubMed]

49. Kuriyama, T.; Ju, X.L.; Fusazaki, S.; Hishinuma, H.; Satou, T.; Koike, K.; Nikaido, T.; Ozoe, Y. Nematocidal quassinoids and bicyclophosphorothionates: A possible common mode of action on the GABA receptor. Pestic. Biochem. Physiol. 2005, 81, 176-187. [CrossRef]

50. Tian, Y.Q.; Zhang, Z.X.; Xu, H.H. Laboratory and field evaluations on insecticidal activity of Cicuta virosa L. var. latisecta Celak. Ind. Crop. Prod. 2013, 41, 90-93. [CrossRef]

51. Wang, Z.; Kim, J.R.; Wang, M.; Shu, S.; Ahn, Y.J. Larvicidal activity of Cnidium monnieri fruit coumarins and structurally related compounds against insecticide-susceptible and insecticide-resistant Culex pipiens pallens and Aedes aegypti. Pest Manag. Sci. 2012, 68, 1041-1047. [CrossRef] [PubMed]

52. Hadacek, F.; Mueller, C.; Werner, A.; Greger, H.; Proksch, P. Analysis, isolation and insecticidal activity of linear furanocoumarins and other coumarin derivatives from Peucedanum (Apiaceae: Apioideae). J. Chem. Ecol. 1994, 20, 2035-2054. [CrossRef] [PubMed]

53. Afek, U.; Carmeli, S.; Aharoni, N. Columbianetin, a phytoalexin associated with celery resistance to pathogens during storage. Phytochemistry 1995, 39, 1347-1350. [CrossRef]

54. Itokawa, H.; Yun, Y.; Morita, H.; Takeya, K.; Lee, S.R. Cytotoxic coumarins from roots of Angelica gigas Nakai. Nat. Med. 1994, 48, 334-335.

55. De Souza, S.M.; Delle, M.F.; Smania, A. Antibacterial activity of coumarins. Z. Naturforsch. 2005, 60C, 693-700. [CrossRef]

56. Meyer, S.L.; Zasada, I.A.; Roberts, D.P.; Vinyard, B.T.; Lakshman, D.K.; Lee, J.K.; Chitwood, D.J.; Carta, L.K. Plantago lanceolata and Plantago rugelii extracts are toxic to Meloidogyne incognita but not to certain microbes. J. Nematol. 2006, 38, 333-338. [PubMed]

57. Viglierchio, D.R.; Schmitt, R.V. On the methodology of nematode extraction from field samples: Baermann funnel modifications. J. Nematol. 1983, 15, 438-444. [PubMed]

58. Adhikari, B.; Devkota, H.P.; Joshi, K.R.; Watanabe, T.; Yahara, S. Two new diacetylene glycosides: Bhutkesoside A and B from the roots of Ligusticopsis wallichiana. Nat. Prod. Res. 2016, 14, 1577-1584. [CrossRef] [PubMed]

59. Radulovi, N.S.; Deki, M.S.; Blagojevi, P.B. Chemical composition of the essential oil and diethyl ether extract of Trinia glauca (L.) Dumort. (Apiaceae) and the chemotaxonomic significance of 5-O-methylvisamminol. Chem. Biocivers. 2016, 13, 403-415. [CrossRef] [PubMed]

60. Macias, F.A.; Hernández-Galán, R.; Massanet, G.M.; Rodriguezluis, F.; Vasquez, M.; Salva, J. ${ }^{13}$ C NMR of coumarins. V 3-prenylated coumarins. Magn. Reson. Chem. 1990, 28, 732-735. [CrossRef]

61. Sakuma, M. Probit analysis of preference data. Appl. Entomol. Zool. 1998, 33, 339-347.

Sample Availability: Samples of the crude extracts and pure compounds are available from the authors.

(C) 2016 by the authors; licensee MDPI, Basel, Switzerland. This article is an open access article distributed under the terms and conditions of the Creative Commons Attribution (CC-BY) license (http:/ / creativecommons.org/licenses/by/4.0/). 